\title{
Evaluation of Prostate specific antigen levels and its correlation with histopathological findings
}

\section{Sujata Pudasaini ${ }^{1}$, Neeraj Subedi ${ }^{2}$, Nagesh Mani Shrestha ${ }^{1}$}

${ }^{I}$ Department of Pathology, Nepal Medical College Teaching Hospital, Jorpati, Nepal

${ }^{2}$ Department of Urology, Nepal Medical College Teaching Hospital, Jorpati, Nepal

\author{
Keywords: \\ Benign prostatic \\ hyperplasia; \\ Carcinoma; \\ Prostate; \\ Prostate specific antigen; \\ Prostatitis;
}

\begin{abstract}
Background: Prostate specific antigen is a tumor marker which is a glycoprotein and is expressed by both normal and neoplastic prostate tissue. The absolute value of Prostate specific antigen is useful for determining the extent of prostate cancer and its treatment. Prostate specific antigen also increases in cases like Benign Prostatic Hyperplasia and prostatitis. The availability of Prostate specific antigen as a marker has encouraged its use to diagnose both cancer and cancer recurrences.
\end{abstract}

Materials and methods: This is a cross sectional study conducted in a tertiary hospital over a period of two years. Cases of prostatic disease undergoing surgery during the study period were taken. Prostate specific antigen level of all these cases were correlated with clinical and histopathological findings.

Results: A total of 51 cases of prostatic disease underwent surgery during the study period with the mean age of $66.57 \pm 10.68$ years. On histopathological examination, $70.6 \%$ had benign prostatic hyperplasia and $17.6 \%$ had prostatic adenocarcinoma. Prostate specific antigen level was $<4 \mathrm{ng} / \mathrm{ml}$ in $45.1 \%$ cases and $>20.1 \mathrm{ng} / \mathrm{ml}$ in $15.7 \%$. In case of carcinoma prostate, $88.9 \%$ had prostate specific antigen level $>$ $20.1 \mathrm{ng} / \mathrm{ml}$ and $11.1 \%$ had prostate specific antigen level in a range of $10.1-20 \mathrm{ng} / \mathrm{ml}$. In case of chronic prostatitis, $66.7 \%$ had prostate specific antigen level in a range of $4.1-10 \mathrm{ng} / \mathrm{ml}$. However, in case of high grade prostatic intraepithelial neoplasia, $66.7 \%$ had PSA level $<4 \mathrm{ng} / \mathrm{ml}$.

Conclusion: Strong correlation of prostate specific antigen levels of $>20.1 \mathrm{ng} / \mathrm{ml}$ with carcinoma prostate was seen.

\section{Correspondence: \\ Dr. Sujata Pudasaini, $M D$}

Associate Professor, Department of Pathology,

Nepal Medical College Teaching Hospital, Kathmandu, Nepal

ORCID ID: 0000-0001-9699-8204

Email:sujatapudasaini@gmail.com

Reveived : March 1 ${ }^{\text {st }} 2019$; Accepted : March14 $4^{\text {th }} 2019$; Published : March $29^{\text {th }} 2019$

Citation: Pudasaini S, Subedi N, Shrestha N. Evaluation of Prostate specific antigen levels and its correlation with histopathological findings. J Pathol Nep 2019;9:1485-9. DOI: 10.3126/jpn. v9i1.23376

Copyright: This is an open-access article distributed under the terms of the Creative Commons Attribution 4.0 International License, which permits unrestricted use, distribution, and reproduction in any medium, provided the original author and source are credited.

\section{INTRODUCTION}

Prostate specific antigen (PSA) is a protein produced by the cells of the prostate gland. Enlargement of prostate gland causes urinary symptoms. ${ }^{1}$ Increased PSA levels is found to be closely associated with prostate cancer. Other reasons for increased PSA could be benign prostatic hyperplasia $(\mathrm{BPH})$, prostatitis or prostatic trauma. ${ }^{2}$ The incidence of prostatic diseases, BPH and carcinoma increases with age. ${ }^{3}$ In physiological condition, PSA is present in very low concentration ( 0.1 to $4.0 \mathrm{ng} / \mathrm{ml})$. PSA is prostate specific but not specific to prostate cancer. ${ }^{4,5}$ The increased value of PSA is found in $20 \%$ to $50 \%$ of men with $\mathrm{BPH} .{ }^{4}$ Approximately $10 \%$ of the male population has a PSA value higher than 10 $\mathrm{ng} / \mathrm{ml}$ but do not have cancer. ${ }^{4}$ 
Table 1: Age group wise distribution of various clinical diagnosis

\begin{tabular}{|c|c|c|c|c|c|c|}
\hline Age group (years) & ВPH & BPH + Vesicular calculi & $\mathrm{Ca}^{*}$ & GUTB** & Susp Ca ${ }^{\neq}$ & Total \\
\hline$<40$ & $0(0 \%)$ & $0(0 \%)$ & $0(0 \%)$ & $1(100 \%)$ & $0(0 \%)$ & $1(100 \%)$ \\
\hline $40-49$ & $2(100 \%)$ & $0(0 \%)$ & $0(0 \%)$ & $0(0 \%)$ & $0(0 \%)$ & $2(100 \%)$ \\
\hline $50-59$ & $6(85.7 \%)$ & $0(0 \%)$ & $0(0 \%)$ & $0(0 \%)$ & $1(14.3 \%)$ & $7(100 \%)$ \\
\hline $60-69$ & $18(100 \%)$ & $0(0 \%)$ & $0(0 \%)$ & $0(0 \%)$ & $0(0 \%)$ & $18(100 \%)$ \\
\hline $70-79$ & $11(57.9 \%)$ & $1(5.3 \%)$ & $3(15.8 \%)$ & $0(0 \%)$ & $4(21.0 \%)$ & $19(100 \%)$ \\
\hline$>80$ & $3(75 \%)$ & $1(25 \%)$ & $0(0 \%)$ & $0(0 \%)$ & $0(0 \%)$ & $4(100 \%)$ \\
\hline Total & $40(78.4 \%)$ & $2(3.9 \%)$ & $3(5.9 \%)$ & $1(2.0 \%)$ & $5(9.8 \%)$ & $51(100 \%)$ \\
\hline
\end{tabular}

*-Carcinoma; ** - Genitourinary tuberculosis; \# Suspicious of Carcinoma

Table 2: Age-group wise frequency of histopathological diagnosis $(n=51)$

\begin{tabular}{cccccc}
\hline Age group (years) & BPH & Adeno Ca & Chronic Prostatitis & HGPIN & Total \\
\hline$<\mathbf{4 0}$ & $0(0 \%)$ & $0(0 \%)$ & $1(100 \%)$ & $0(0 \%)$ & $1(100 \%)$ \\
$\mathbf{4 0 - 4 9}$ & $2(100 \%)$ & $0(0 \%)$ & $0(0 \%)$ & $0(0 \%)$ & $2(100 \%)$ \\
$\mathbf{5 0 - 5 9}$ & $5(71.4 \%)$ & $2(28.6 \%)$ & $0(0 \%)$ & $0(0 \%)$ & $7(100 \%)$ \\
$\mathbf{6 0 - 6 9}$ & $16(88.8 \%)$ & $0(0 \%)$ & $1(5.6 \%)$ & $1(5.6 \%)$ & $18(100 \%)$ \\
$\mathbf{7 0 - 7 9}$ & $10(52.6 \%)$ & $7(36.8 \%)$ & $1(5.3 \%)$ & $1(5.3 \%)$ & $19(100 \%)$ \\
$>\mathbf{8 0}$ & $3(75 \%)$ & $0(0 \%)$ & $0(0 \%)$ & $1(25 \%)$ & $4(100 \%)$ \\
\hline Total & $\mathbf{3 6}(\mathbf{7 0 . 6} \%)$ & $\mathbf{9 ( 1 7 . 6 \% )}$ & $\mathbf{3 ( 5 . 9 \% )}$ & $\mathbf{3 ( 5 . 9 \% )}$ & $\mathbf{5 1 ( 1 0 0 \% )}$ \\
\hline
\end{tabular}

Variations of PSA level could be due to genetic factors or many other factors that influence PSA level. Age specific reference range of PSA has the possibility to make it a good tumor marker for prostate cancer in older men. This can also be used for early detection of cancer in young men. ${ }^{6-8}$ PSA is the most useful tumor marker in diagnosis and first line test in screening. ${ }^{3}$ PSA levels are influenced by the patient's age and prostatic size. In healthy elderly male with no evidence of prostatic cancer, PSA increases by $3.2 \%$ per year. PSA value varies not only with advancing age but also with different geographical areas. ${ }^{9}$ The availability of PSA as a marker has encouraged its use to diagnose both cancer and cancer recurrences. This study was conducted with the aim of finding out the level of PSA in prostate disease and to compare the PSA levels in different age group and to find out their correlation with histopathological diagnosis.

\section{MATERIAL AND METHODS}

This is a cross sectional study conducted in a tertiary hospital, Nepal Medical College Teaching Hospital over a period of two years (January 2017 to December 2018). Ethical clearance to carry out the study was obtained from Institutional Review Committee (IRC) of the institute. All the cases of prostate disease presenting to Urology department and undergoing surgery during the study period were taken. PSA levels were estimated in VITROS ECiQ Immunodiagnostic System - Ortho Clinical Diagnostics. Related clinical findings were obtained from the patient's medical record file. Prostatic biopsies were sent to department of Pathology for evaluation. These biopsies were fixed overnight in $10 \%$ formalin, processed in automatic tissue processor (Yorco) and paraffin blocks were prepared. Paraffin embedded sections were stained with Hematoxylin and Eosin ( $\mathrm{H}$ and $\mathrm{E}$ ) for histopathological examination and diagnosis. The data were then entered and descriptive analysis was performed in Microsoft office excel 2003.

\section{RESULTS}

There were total of 51 cases of prostatic diseases, of which both PSA and histopathology was done. The mean age \pm SD of the patient with prostatic disease was $66.57 \pm 10.68$ years. The youngest patient was 35 years old and eldest patient was 89 years old. The most affected group with prostatic disease was $70-79$ years $(n=19 ; 37.3 \%)$ followed by $60-69$ years $(n=18 ; 35.3 \%)$. BPH was the most common clinical $(\mathrm{n}=40 ; 78.4 \%)$ as well as histopathological diagnosis $(n=36 ; 70.6 \%)$. (Table 1 and 2 ) There were 9.8\% clinically suspicious carcinoma cases and $5.9 \%$ clinically diagnosed carcinoma cases. High Grade Prostatic Intraepithelial Neoplasia (HGPIN) was diagnosed in 5.9\% cases on histopathology. (fig. 1)

Table 3 shows clinical and histopathological diagnosis of all the cases. Different PSA value was seen in different age groups (Table 4). All the cases of clinically diagnosed carcinoma and clinically suspicious carcinoma had PSA level $>20.1 \mathrm{ng} / \mathrm{ml}$. (Table 5) There were 9 cases $(17.6 \%$ ) of carcinoma prostate diagnosed on histopathology and out of that 8 cases $(88.9 \%)$ had PSA of $>20.1 \mathrm{ng} / \mathrm{ml}$. Higher range of PSA level was seen in chronic prostatitis, with $66.7 \%$ cases having PSA of 4.1-10 ng/ml and 33.3\% cases having PSA of $10.1-20 \mathrm{ng} / \mathrm{ml}$. Out of 36 cases of BPH, $58.3 \%$ had 
Table 3: Clinical and Histopathological diagnosis of prostatic lesions $(n=51)$

\begin{tabular}{|c|c|c|c|c|c|}
\hline Clinical diagnosis & Number & Percentage & Biopsy Diagnosis & Number & Percentage \\
\hline BPH & 40 & $78.4 \%$ & BPH & 36 & $70.6 \%$ \\
\hline $\begin{array}{l}\text { BPH with vesicular } \\
\text { calculi }\end{array}$ & 02 & $3.9 \%$ & Chronic Prostatitis & 03 & $5.9 \%$ \\
\hline GUTB & 01 & $2.0 \%$ & HGPIN & 03 & $5.9 \%$ \\
\hline Ca prostate & 03 & $5.9 \%$ & Ca Prostate & 09 & $17.6 \%$ \\
\hline Suspicious for Ca & 05 & $9.8 \%$ & & & \\
\hline Total & 51 & $100 \%$ & Total & 51 & $100 \%$ \\
\hline
\end{tabular}

Table 4: PSA range in different age group $(n=51)$

\begin{tabular}{|c|c|c|c|c|c|}
\hline \multirow{2}{*}{ Age (years) } & \multicolumn{5}{|c|}{ PSA (ng/ml) } \\
\hline & $<4$ & 4.1-10 & $10.1-20$ & $>20.1$ & Total \\
\hline$<40$ & $0(0 \%)$ & $1(100 \%)$ & $0(0 \%)$ & $0(0 \%)$ & $1(100 \%)$ \\
\hline $40-49$ & $2(100 \%)$ & $0(0 \%)$ & $0(0 \%)$ & $0(0 \%)$ & $2(100 \%)$ \\
\hline $50-59$ & $3(42.8 \%)$ & $1(14.3 \%)$ & $1(14.3 \%)$ & $2(28.6 \%)$ & $7(100 \%)$ \\
\hline $60-69$ & $10(55.5 \%)$ & $3(16.7 \%)$ & $5(27.8 \%)$ & $0(0 \%)$ & $18(100 \%)$ \\
\hline $70-79$ & $8(42.1 \%)$ & $3(15.8 \%)$ & $2(10.5 \%)$ & $6(31.6 \%)$ & $19(100 \%)$ \\
\hline$>80$ & $0(0 \%)$ & $2(50 \%)$ & $2(50 \%)$ & $0(0 \%)$ & $4(100 \%)$ \\
\hline Total & $23(45.1 \%)$ & $10(19.6 \%)$ & $10(19.6 \%)$ & $8(15.7 \%)$ & $51(100 \%)$ \\
\hline
\end{tabular}

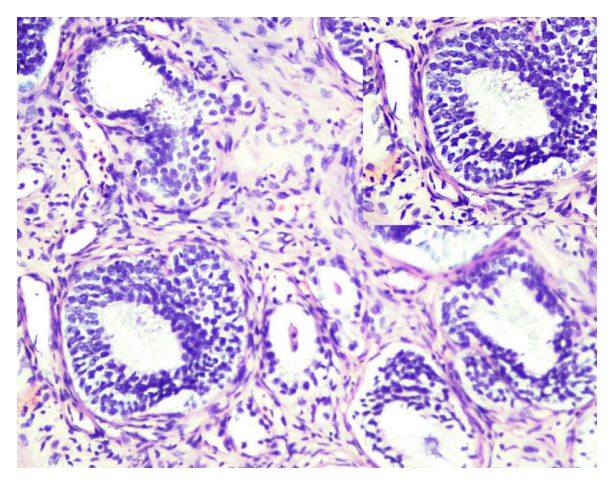

Figure 1: High Grade Prostatic Intraepithelial Neoplasia (HGPIN); (HE stain; X200). Inset showing in high power view.

PSA $<4 \mathrm{ng} / \mathrm{ml}, 19.4 \%$ had PSA level of $4.1-10 \mathrm{ng} / \mathrm{ml}$ and $22.2 \%$ had PSA level of 10.1-20 ng/ml. (Table 6)

All the cases of prosatatic carcinoma were adenocarcinoma. The new grading system (5 Grade Group system), 2016 World Health Organization (WHO) for prostate cancer was used for grading all these cases. Out of the total cases, 55.6\% cases were Grade Group 4 (Gleason score 8; fig. 2) and 44.4\% were Grade Group 5 (Gleason score 9-10; fig. 3).

\section{DISCUSSION}

Serum PSA levels can be influenced by any inflammation of the prostate and its mechanical stimulation. ${ }^{6}$ Benign prostatic hyperplasia and prostate carcinoma are increasing

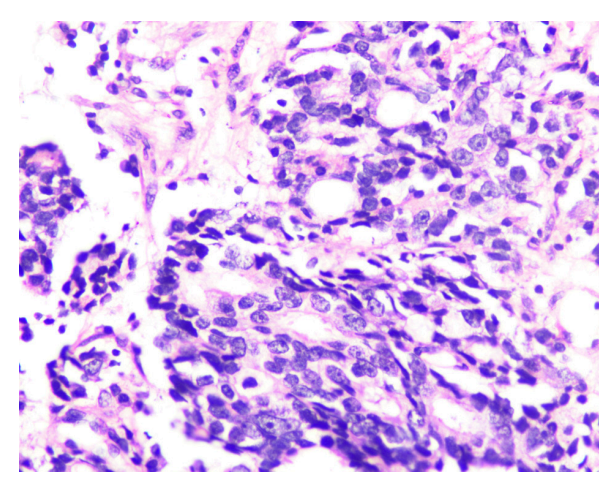

Figure 2: Carcinoma prostate with Gleason grade 4. (HE stain; X200)

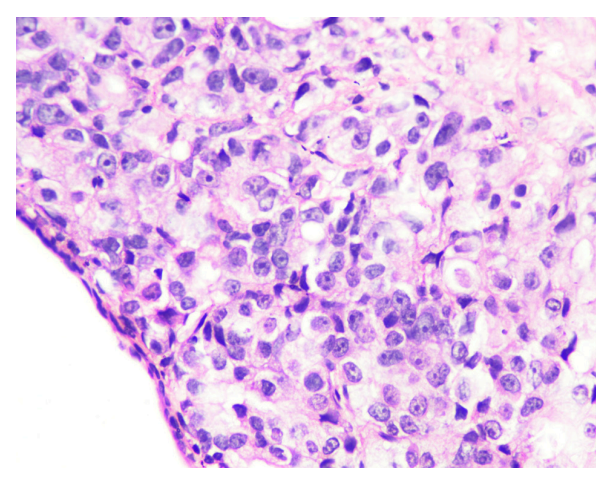

Figure 3: Carcinoma prostate with Gleason grade 5 (HE stain; X400)

in number with advancing age and are usually uncommon before the age of 40 years. 10 Clinically applicable reference value for PSA is $0-4.0 \mathrm{ng} / \mathrm{ml}$ but they don't point out the 
Table 5: Clinical diagnosis and PSA range

\begin{tabular}{|c|c|c|c|c|c|}
\hline \multirow{2}{*}{ Clinical Diagnosis } & \multicolumn{5}{|c|}{ PSA (ng/ml) } \\
\hline & $<4$ & 4.1-10 & $10.1-20$ & $>20.1$ & Total \\
\hline ВPH & $22(55 \%)$ & $8(20 \%)$ & $9(22.5 \%)$ & $1(2.5 \%)$ & $40(100 \%)$ \\
\hline BPH with vesicular calculi & $1(50 \%)$ & $1(50 \%)$ & $0(0 \%)$ & $0(0 \%)$ & $2(100 \%)$ \\
\hline GUTB & $0(0 \%)$ & $1(100 \%)$ & $0(0 \%)$ & $0(0 \%)$ & $1(100 \%)$ \\
\hline Ca prostate & $0(0 \%)$ & $0(0 \%)$ & $0(0 \%)$ & $3(100 \%)$ & $3(100 \%)$ \\
\hline Suspicious for Ca & $0(0 \%)$ & $0(0 \%)$ & $1(20 \%)$ & $4(80 \%)$ & $5(100 \%)$ \\
\hline Total & $23(45.1 \%)$ & $10(19.6 \%)$ & $10(19.6 \%)$ & $8(15.7 \%)$ & $51(100 \%)$ \\
\hline
\end{tabular}

Table 6: Histopathological diagnosis and PSA range

\begin{tabular}{|c|c|c|c|c|c|}
\hline \multirow{2}{*}{ Histopathological Diagnosis } & \multicolumn{5}{|c|}{ PSA (ng/ml) } \\
\hline & $<4$ & 4.1-10 & $10.1-20$ & $>20.1$ & Total \\
\hline ВPH & $21(58.3 \%)$ & $7(19.4 \%)$ & $8(22.2 \%)$ & $0(0 \%)$ & $36(100 \%)$ \\
\hline Ca Prostate & $0(0 \%)$ & $0(0 \%)$ & $1(11.1 \%)$ & $8(88.9 \%)$ & $9(100 \%)$ \\
\hline Chronic Prostatitis & $0(0 \%)$ & $2(66.7 \%)$ & $1(33.3 \%)$ & $0(0 \%)$ & $3(100 \%)$ \\
\hline HGPIN & $2(66.7 \%)$ & $1(33.3 \%)$ & $0(0 \%)$ & $0(0 \%)$ & $3(100 \%)$ \\
\hline Total & $23(45.1 \%)$ & $10(19.6 \%)$ & $10(19.6 \%)$ & $8(15.7 \%)$ & $51(100 \%)$ \\
\hline
\end{tabular}

absence of carcinoma always. PSA value of 4.0- $10.0 \mathrm{ng}$ / $\mathrm{ml}$ could be present in patients with $\mathrm{BPH}$, prostatitis, intraepithelial neoplasia and prostate carcinoma. ${ }^{11}$

The result of our study showed that prostatic diseases were more common after 40 years. The mean age of the patient with prostatic disease was $66.57 \pm 10.685$ years. This correlates with several studies. ${ }^{1,2,4,6}$ Maximum number of patients were in age group $70-79$ years followed by $60-69$ years. This finding was similar to studies done in different parts of India. ${ }^{1,2,6}$ A study done in Kathmandu valley showed that the maximum number of patients with prostatic disease was seen in 61-70 years age group. ${ }^{10}$

There were 36 cases $(70.6 \%)$ of $\mathrm{BPH}$ with maximum number of cases in age group 60- 69 years. There was no case of BPH in patient less than 40 years and only $5.6 \%$ cases in age group 40- 49 years. This showed that BPH cases increases with increasing age. Majority $(58.3 \%)$ of the BPH cases in our study had PSA level $<4 \mathrm{ng} / \mathrm{ml}$. None of the BPH cases had PSA level $>20.1 \mathrm{ng} / \mathrm{ml}$. Chronic prostatitis was seen in $5.9 \%$ cases with $66.7 \%$ having PSA range of $4.1-10 \mathrm{ng} / \mathrm{ml}$ and $33.3 \%$ having PSA range of 10.1-20ng/ $\mathrm{ml}$. Our finding was very similar to the finding in a study done by Hirachand $\mathrm{S}$ et al where $\mathrm{BPH}(74.2 \%)$ was the most common histological lesion seen in age group 61-70 years and among these $73.4 \%$ had PSA range of $0-7 \mathrm{ng} / \mathrm{ml}$. Prostatits was seen in $5.5 \%$ cases and $71 \%$ of prostatitis had PSA range of 0-7 ng/ml. ${ }^{10}$ Benerjee B et al also showed that $\mathrm{BPH}, \mathrm{BPH}$ with prostatitis and only prostatitis were seen in $38.8 \%, 28.75 \%$ and $7.5 \%$ cases respectively and all these benign cases had PSA range of $0-7 \mathrm{ng} / \mathrm{ml} .{ }^{1}$ Similarly other studies also showed that PSA level is usually $<20 \mathrm{ng} / \mathrm{ml}$ in case of benign conditions like BPH. ${ }^{12,13}$

Prostatic intraepithelial neoplasia was seen in $5.9 \%$ cases in our study and all the cases were HGPIN with PSA level $<10 \mathrm{ng} / \mathrm{ml}$. The studies done in two different parts of India showed similar finding ( $1.8 \%$ cases of PIN in each study) and the PSA level was $<10 \mathrm{ng} / \mathrm{ml}^{2,13}$ Other studies showed $10 \%$ and $10.2 \%$ cases of PIN where PSA level was $<14 \mathrm{ng}$ / $\mathrm{ml}$. ${ }^{1,10}$ Study had suggested that HGPIN is associated with carcinoma and usually if it is so the incidence of HGPIN is high as $78.9-88 \% .^{14,15}$ However, in our study there was no HGPIN associated carcinoma.

There were $17.6 \%$ cases of carcinoma prostate in our study. Majority of the malignant cases $(77.8 \%)$ were seen in age group 70- 79 years. $88.9 \%$ had PSA level $>20 \mathrm{ng} / \mathrm{ml}$. Similar finding was seen in several other studies. ${ }^{10,12,15}$ In a study done by Sridevi $\mathrm{N}$ et al, all the cases of carcinoma prostate showed significant elevation of PSA > $20 \mathrm{ng} / \mathrm{ml}^{16}$

All the cases of carcinoma prostate were adeno carcinoma. According to new grading system (5 Grade Group system), 2016 World Health Organization (WHO) for prostate cancer, $55.6 \%$ cases were Grade Group 4 with Gleason score of 8 and 44.4\% were Grade Group 5 with Gleason score of 9-10. In contrast to our study, Yelda D et al showed 5.6\% cases in Grade Group 5 with maximum cases of adeno carcinoma in Grade Group 2. ${ }^{15}$ Khant VS et al. showed 26.8\% cases in Grade group 5. ${ }^{13}$

Studies which do not use the 5 Grade Group system had 
graded tumor according to Gleason score. Bikkasani $\mathrm{K}$ et al found $20.7 \%$ cases with Gleason score of 8-10 in their study. ${ }^{12}$ Similarly, Gleason score of 7 was seen in $51.6 \%$ and $15 \%$ cases respectively in studies done by Jaypradeep DP et al and Carter HB et al., ${ }^{2,17}$

The reason for high Gleason score in our study could be due to the late presentation of the disease. The rate of change in PSA appears to be greater in men with prostate carcinoma compared with men without disease. The change may occur at a time when the disease is not clinically evident. Hence, serial measurement of PSA may be a useful clinical marker of prostate carcinoma. ${ }^{18}$

\section{CONCLUSION}

Serum PSA is a sensitive marker for prostatic disease and value of $>4 \mathrm{ng} / \mathrm{ml}$ is usually associated with prostatic disease. PSA is raised in both neoplastic and non neoplastic conditions. With increasing PSA, chance of carcinoma prostate is also high.

\section{Acknowledgement}

We would like to thank Dr Nishchal Dhakal from Department of Community Medicine for helping us in the statistical analysis of data.

\section{Conflict of Interest: None}

\section{REFERENCES}

1. Banerjee B, Iqbal BM, Kumar H, Kambale T, Bavikar R. Correlation between prostate specific antigen levels and various pathologies. J Med Soc. 2016;30:172-5. $\underline{\text { Crossref }}$

2. Jayapradeep DP, Prakash VB, Philipose TR, Pai MR. Histomorphological correlation of PSA levels in prostatic carcinoma. National J Lab Med. 2017; 6: 28-32.

3. Resim S, Cek M, Gurbuz ZG et al. Serum PSA and age specific reference ranges in patients with prostatism symptoms. Int Urol Nephrol. 1999;31:221-8. $\underline{\text { Crossref }}$

4. Prcic A, Begic A, Hiros M. Usefulness of total PSA value in prostate diseases diagnosis. Acta Inform Med. 2016;24:156-61. Crossref

5. Putra Ida Bagus OW, Hamid Agus RAH, Mochtar Chaidir A, Umbas R. Relationship of age, prostate specific antigen and prostate volume in Indonesian men with benign prostatic hyperplasia. Prostate Int. 2016;4:43-8. . Crossref
6. Ingle SP, Ingle R, Sukesh. The efficiency of the serum prostate specific antigen levels in diagnosing prostatic enlargements. J Clin Diagn Res. 2013;7:82-4.

7. Luboldt HJ, Schindler JF, Rubben H. Age specific reference ranges for prostate specific antigen as a marker for prostate cancer. European Assoc Urol . 2007;5:38-48. $\underline{\text { Crossref }}$

8. Mittal RD. Reference range of serum prostate specific antigen levels in Indian men. Indian J Med Res. 2014;140:480-1. Crossref

9. Constantinou J, Feneley MR. PSA testing: an evolving relationship with prostate cancer screening. Prostate Cancer Prostatic Dis. 2006;9:6-13. Crossref

10. Hirachand S, Dangol UMS, Pradhanang S, Acharya S. Study of prostatic pathology and its correlation with prostate specific antigen. J Pathol Nepal. 2017;7:1074-7. Crossref

11. Zivkovic S. Correlation between prostate specific antigen and histopathological difference of prostate carcinoma. Arch Oncol. 2004;12:148-51. $\underline{\text { Crossref }}$

12. K Bikkasani, SK Kanakmedala, S Sinha, SR Siriguri. Prostate biopsy findings in Indian men: a hospital based study. Indian J of Cancer. $201 ; 48: 175-80$. $\underline{\text { Crossref }}$

13. Khant VS, Goswami H, Shah PY. Correlation of serum prostate specific antigen level in various prostate pathology in elderly men. Int J Med Sci Public Health. 2017;6:257-61. $\underline{\text { Crossref }}$

14. Alexander EE, Qian J, Wollan PC, Myers RP, Bostwick DG. Prostatic intraepithelial neoplasia does not appear to raise serum prostate specific antigen concentration. Urology. 1996; 47:693-8. Crossref

15. Yelda D, Akarken I, Sahin H. The role of preoperative PSA level in prostate cancer. Int J Adv Med. 2018;5:780-3. Crossref

16. Sridevi N. Comparative study of prostatic diseases BPH and prostatic cancer by estimating serum PAP and total PSA level. J Pharm Biol Sci. 2013;8:44-7.

17. Carter HB. Prostate cancers in men with PSA levels - must we find them? N Engl J Med. 2004;350:2292. $\underline{\text { Crossref }}$

18. Carter HB, Pearson JD, Metter EF. Longitudinal evaluation of prostate specific antigen levels in men with and without prostate disease. J American Med Assoc. 1992;267:2215-20. Crossref 